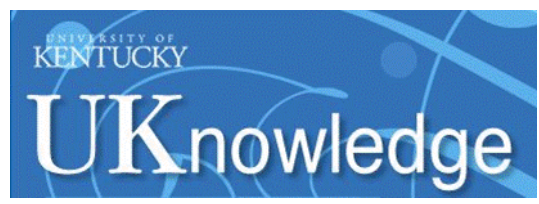

University of Kentucky

UKnowledge

2014

\title{
Adolescence and Sexuality
}

Joav Merrick

National Institute of Child Health and Human Development, Israel

Ariel Tenenbaum

National Institute of Child Health and Human Development, Israel

Hatim A. Omar

University of Kentucky, hatim.omar@uky.edu

Follow this and additional works at: https://uknowledge.uky.edu/pediatrics_facpub

Part of the Gender and Sexuality Commons, International Public Health Commons, Obstetrics and Gynecology Commons, and the Pediatrics Commons

Right click to open a feedback form in a new tab to let us know how this document benefits you.

\section{Repository Citation}

Merrick, Joav; Tenenbaum, Ariel; and Omar, Hatim A., "Adolescence and Sexuality" (2014). Pediatrics

Faculty Publications. 248.

https://uknowledge.uky.edu/pediatrics_facpub/248

This Book Chapter is brought to you for free and open access by the Pediatrics at UKnowledge. It has been accepted for inclusion in Pediatrics Faculty Publications by an authorized administrator of UKnowledge. For more information, please contact UKnowledge@lsv.uky.edu. 


\section{Adolescence and Sexuality}

\section{Notes/Citation Information}

Published in Adolescence and Sexuality: International Perspectives. Joav Merrick, Ariel Tenenbaum, \& Hatim A. Omar, (Eds.). p. 3-6.

(c) 2014 Nova Science Publishers, Inc.

The copyright holder has granted permission for posting the chapter here. 


\section{Chapter 1}

\section{ADOLESCENCE AND SEXUALITY}

\section{Joav Merrick, MD, MMedSc, DMSc $c^{1,2,3,4,}$, Ariel Tenenbaum, $\mathrm{MD}^{1,3}$ and Halim A Omar, MD, FAAP'}

${ }^{1}$ National Institute of Child Health and Human Development, Jerusalem, Israel

${ }^{2} 0$ ffice of the Medical Director, Health Services, Division for Intellectual and Developmental Disabilities, Ministry of Social Affairs and Social Services, Jerusalem, Israel

${ }^{3}$ Division of Pediatrics, Hadassah Hebrew University Medical Center, Mt Scopus Campus, Jerusalem, Israel

${ }^{\mathbf{4}}$ Division of Adolescent Medicine, Kentucky Children's Hospital, University of Kentucky, Lexington, Kentucky, US

Human sexuality involve sexual attraction to another person, which for the most part is to the opposite sex (heterosexuality), some to the same sex (homosexuality) or some having both (bisexuality) or not being attracted to anyone in a sexual manner (asexuality).

* Correspondence: Professor Joav Merrick, MD, MMedSci, DMSc, Medical Director, Health Services, Division for Intellectual and Developmental Disabilities, Ministry of Social Affairs and Social Services, POBox 1260, IL-91012 Jerusalem, Israel. E-mail: jmerrick@zahav.net.il. 
Human sexuality is determined by many factors, like cultural, political, legal and philosophical aspects of life, but also morality, ethics, theology, spirituality and religion. Sexuality is as old as mankind and interest in sexual activity is very much related to the onset of puberty and the period of schooling.

Primary care physicians see children and adolescents with a wide variety of gynecologic and sexual needs, though they often have limited training andlimited available educational materials to help them. We therefore published a small handbook on pediatric and adolescent gynecology with information for the primary care clinician (1), but in this book we have gathered papers from around the world in order to discuss issues of sexuality from an international perspective.

Children and adolescents must successfully traverse various stages of pubertal and sexual development in order to become well-adjusted adults with established sexual identity, functioning and ability. Concerns with breast development and menstrual function are common issues with adolescent females. The clinician may be presented with children who have pediatric gynecologic complaints (i.e., vulvar bleeding, itching, or a mass) or an adolescent who needs contraception or pregnancy counseling.

The United States 2005 Youth Risk Behavior Survey (YRBS) noted that $46.8 \%$ of all high school students have had sexual (coital) experience, with a range of $43.0 \%$ for Whites, $51.0 \%$ for Hispanics, and $67.6 \%$ for AfricanAmerican youth. These millions of sexually active youth produce about 900,000 pregnancies and over six million sexually transmitted diseases (STDs) each year, one in 10 of adolescent females become pregnant each year, $90 \%$ of which were unintended. In adolescents, $14 \%$ of the pregnancies end in miscarriages, $35 \%$ in abortions and $51 \%$ in live births. Pregnancy rates and STD numbers are also significant around the world, including European countries.

Studies note that youth (age 15-19 years) have the highest rates of chlamydia, gonorrhea cervicitis (endocervicitis), syphilis and hospitalizations due to pelvic inflammatory disease. Worldwide, those individuals 15-29 years of age have the highest STD risk. Increased risk of youth for STDs is due to high sexual activity rates, multiple sex partners, use of sex and drugs concomitantly, immature cervix (sensitive transition zone cells exposed to the vaginal environment), "adolescence myth" thinking (i.e., no harm will ever come to one, despite high risk behavior), and difficulty in dealing with the medical system for prevention, screening, diagnosis and treatment. The cost in terms of preventable health care spending is staggering and the complications 
of STDs are severe, especially for females; these include pelvic inflammatory disease, chronic pelvic pain, ectopic (tubal) pregnancy and poor pregnancy outcomes, HPV-induced cervical cancer, and others.

In the United States, in 2005, there were 1,225 newly diagnosed cases of HIV/AIDS among adolescents 15-19 years old, and 3,904 among young adults aged 20-24 years (out of 200,000 cases in the United States). There is an estimated one million Americans, who are infected with HIV; it is unknown how many are teenagers who will eventually die from HIV in their third or fourth decade of life. Approximately $20 \%$ of adults with HIV infection were infected as teenagers and one in four individuals newly diagnosed with HIV infection is under age 22 years. African-Americans are 14\% of the American population, yet they bear $28 \%$ of the AIDS cases in America. It is estimated that nearly 100,000 women in the United Kingdom develop pelvic inflammatory disease (PID) each year. After one episode of STI/STD, 12.8\% of young women will suffer from tubal infertility; after three episodes, this figure rises to $75 \%$. However, because most primary care providers do not deal with the complex treatment of AIDS, we will not include a chapter on the subject in this book.

There are approximately three million reported annual cases of abuse in America in those under 18 years of age; in 2004 reported cases of maltreatment were subdivided into neglect in $62.4 \%$, physical abuse in $17.5 \%$, sexual abuse in $9.7 \%$, emotional or psychological abuse in $7 \%$, and medical neglect in $2.1 \%$ of total cases (2). The epidemiology of rape suggests that, while fewer than one-third of rapes get reported, in three-quarters of cases the perpetrator is known to the woman/victim. The child or adolescent who is subjected to violence and abuse may become an adult with serious sequelae, including diverse mental health disorders. Many cases of physical abuse of children start out as an attempted sexual abuse and the physical injuries happen as the perpetrator is suppressing the victim's struggle and resistance.

The shortage of child and adolescent gynecologists in the world has placed considerable strain on primary care clinicians in helping these children and adolescents, who have a wide variety of sexual and gynecologic needs. The inadequate training primary care clinicians often receive in this area is also worsened by the limited number of available books written for them, which was the reason why we did the pediatric and adolescent gynecology book (1).

In this present book we bring current international research in the hope that it will be of interest fro you as the reader and will bring knowledge from an international perspective. 


\section{REFERENCE}

[I] Omar HA, Greydanus HA, Tsitsika AK, Patel DR, Merrick J, eds. Pediatric and adolescent sexuality and gynecology. Principles for the primary care clinician. New York: Nova Science, 2010. 